\author{
Katarzyna Trusewicz \\ Wydział Filologiczny \\ Uniwersytet w Białymstoku \\ e-mail: katarzynatrusewicz@gmail.com
}

\title{
Ekogawędy Simony Kossak
}

Działalność Simony Kossak (1943-2007) była ściśle związana z obszarem Puszczy Białowieskiej, w której jako badaczka zaangażowana w walkę o przyrodę spędziła trzydzieści pięć lat życia. Zanim rozpoczęła pracę w Zakładzie Badania Ssaków PAN w Białowieży, ukończyła studia na Wydziale Biologii i Nauk o Ziemi Uniwersytetu Jagiellońskiego ze specjalizacją psychologa zwierząt. Dzięki awansom naukowym (w 2000 roku uzyskała tytuł naukowy profesora nauk leśnych), licznym publikacjom oraz pracy na rzecz ochrony roślin i zwierząt, pełniła również obowiązki kierownika Zakładu Lasów Naturalnych Instytutu Badawczego Leśnictwa w Białowieży.

W 1987 roku w rozmowie ze Zbigniewem Święchem Kossak tak oto charakteryzowała swój stosunek do przyrody:

Mieszkając tak długo w Puszczy Białowieskiej [...] w pewnej chwili zrozumiałam, że przekroczyłam kordon i znalazłam się [...] po stronie drzew i zwierząt. Występuję więc w ich imieniu. Skończyłam studia biologiczne ze specjalizacją psychologii zwierząt, lecz dopiero lata życia w lesie nauczyły mnie rozumieć mowę zwierząt. I znam ją tak dobrze, że należałoby mnie spalić na stosie jako czarownicę. [...]. I dziś mogę już przekazać innym, że puszcza woła o ratunek dla swoich zwierząt ${ }^{1}$.

\footnotetext{
1 S. Kossak, Mit szlachetnych łowów, z Simoną Kossak rozm. Zbigniew Święch, „Życie Warszawy" 19-20.12.1987, s. 3.
} 
Określając siebie jako przedstawicielkę drzew i zwierząt, czyli tę, „,która przekroczyła kordon", badaczka wyraźnie podkreśla, że stało się to nie za sprawą wiedzy zdobytej na wyższej uczelni, ale dzięki praktyce życia codziennego, które przez ponad trzydzieści lat wiodła w cieniu starych drzew Puszczy Białowieskiej. Będąc świadkiem negatywnego podejścia do przyrody nie tylko ludzi zamieszkujących obszar Puszczy Białowieskiej, ale również biologów i leśniczych, Kossak przechodzi od teorii do praktyki i podejmuje działania mające na celu ochronę natury. Szczególną uwagę należy zwrócić na jej wypowiedzi zarówno ustne, jak i pisemne, mające często charakter literacki. Nie można też pominąć jej życiowej postawy, która charakteryzowała się wrażliwością wobec natury. Niniejszy tekst obejmuje jedynie skromny wycinek ogromnej działalności Simony Kossak, prowadzonej na różnych polach i będącej specyficznym splotem różnych praktyk ${ }^{2}$. Chciałabym poddać analizie jedną $\mathrm{z}$ nich, gawędę, traktowaną tu jako formę aktywności zaangażowanej. Gawędom Kossak przypisuję przedrostek „eko-" w celu podkreślenia ich związku ze środowiskiem naturalnym. Celem ich autorki nie było bowiem jedynie dostarczenie odbiorcy "twardej” wiedzy o zwierzętach, dotyczącej np. ich pożywienia czy legowiska. Wydaje mi się, że „ekogawędę" można rozpatrywać jako praktykę społeczną, nastawioną na uwrażliwienie na los zwierząt.

Na początku lat 90. Simona Kossak podczas spotkania z Jerzym Leszczyńskim, które odbyło się po słynnej aferze białowieskiej (w której Kossak toczyła batalię o uratowanie od zagłady rysiów i wilków ${ }^{3}$ ), sugerowała,

2 Simona Kossak, oprócz pracy naukowej, zajmowała się również popularyzacją wiedzy o zwierzętach w różnych formach: poprzez gawędy radiowe, teksty literackie czy filmy dokumentalne.

3 Simona Kossak, prekursorka walk w obronie zwierząt, pierwszą poważną batalię stoczyła na początku lat 90. W tym czasie w Puszczy Białowieskiej pojawili się naukowcy z Zakładu Badania Ssaków, którzy dostali pozwolenie od dyrekcji Białowieskiego Parku Narodowego oraz ministra na odłów wilków i rysi w celu badań telemetrycznych (metoda ta polega na założeniu specjalnej obroży z nadajnikiem radiowym; zwierzę, żyjące w swoim naturalnym środowisku, przesyła dzięki niej informacje). Główny zarzut Kossak dotyczył odłowu zwierząt, który w Polsce jest zakazany prawem - badacze chcieli zastosować ciężkie metalowe potrzaski, które zostały sprowadzone przez nich ze Stanów Zjednoczonych. W 1993 roku Simona Kossak, w trakcie wędrówki po ścisłym rezerwacie, natknęła się na dwa potrzaski, które postanowiła zabrać ze sobą do domu. Została oskarżona o kradzież, a sprawa otarła się o wokandę sądową. Postępowanie wobec Kossak zostało umorzone, a zarzuty skierowane wobec naukowców z Zakładu Badania Ssaków. Ostatecznie Prokuratura Rejonowa w Hajnówce umorzyła postępowanie. Naukowcy zrezygnowali z niebezpiecznej metody odławiania ssaków, jednak mogli dalej prowadzić badania. Simona Kossak działała na rzecz ochrony przyrody nie tylko w Puszczy Białowieskiej. Dzięki zaangażowaniu oraz autorytetowi w środowisku naukowym została członkiem Lokalnej Komisji Etycznej w Białymstoku w latach 2000-2006, a od 2005 przewodniczyła Radzie Nauko- 
że tematy przyrodnicze powinno podejmować radio. Dziesięć lat później, w roku 2001 rozpoczęły się nagrania dla Polskiego Radia Białystok, które z Leszczyńskim realizował Jarosław Iwaniuk.

Ucieszyła się, gdy zaproponowaliśmy jej współpracę - wspomina Iwaniuk - i od razu się zgodziła. Ktoś w radiu wpadł na pomysł tytułu audycji: Co w trawie piszczy? Simona na to: "A kogo to obchodzi, co piszczy? Dlaczego w trawie piszczy? - oto jest pytanie!" ${ }^{4}$.

Pierwsze nagrania powstawały w naturalnych plenerach Puszczy Białowieskiej. Gawędy miały tysiące wiernych odbiorców, którzy słuchali audycji od poniedziałku do piątku na antenie Polskiego Radia Białystok. W trakcie sześciu lat intensywnej współpracy powstało prawie dwa tysiące gawęd, emitowanych w sekwencjach trwających od 3 do 4 minut. Tu należy zaznaczyć, że Simona Kossak nigdy nie spisała swoich gawęd, dopiero po jej śmierci pojawiły się inicjatywy utrwalenia ich $\mathrm{w}$ formie pisemnej. W efekcie powstały dwa popularne albumy: Dlaczego w trawie piszczy? Gawędy Simony Kossak ${ }^{5}$, którego narracja została podporządkowana czterem porom roku oraz Serce i pazur. O uczuciach zwierząt ${ }^{6}$. W pierwszym zbiorze gawęd teksty dotyczące wiosny objęte są tytułem Ptasie dialekty, część dotycząca lata jest zatytułowana Latanie to wyzwanie, jesienne zwyczaje zwierząt omówione są w rozdziale Zwierzęce ścielenie łóżek, a gawędy zimowe zebrane są pod tytułem Przyroda nie lubi spokoju. Album ten, ze względu na ogromną popularność, został uhonorowany Podlaską Marką Roku 2009 w kategorii przedsięwzięcie. Chciałabym przyjrzeć się innej książce, której podtytuł stawia przed czytelnikiem poważne wyzwanie. Serce $i$ pazur. O uczuciach zwierząt to tytuł sugerujący, że nie należy traktować zwierząt jako kierujących się, w opozycji do ludzkiego rozumu, instynktem. Poglądu takiego dostarczył Kartezjusz w Rozprawie o metodzie, rozwijając metafizyczną teorię bytu, podzielonego na dwie substancje: rozciągłą (res extensa) i myślącą (res cogitans).

wej Białowieskiego Parku Narodowego. Dzięki temu miała wpływ na sposób prowadzenia badań naukowych na roślinach i zwierzętach. Zob. A. Kamińska, Simona. Opowieść o niezwyczajnym życiu Simony Kossak, Kraków 2015, s. 225-233.

4 Tamże, s. 246.

5 Dlaczego w trawie piszczy? Gawędy Simony Kossak, red. A. Andrejszuk, A. Kaczanowski, M. Krawczyk, M. Radecka, Białystok 2009. Publikacja zawiera osiemdziesiąt wybranych przez redaktorów gawęd wygłoszonych przez Simonę Kossak w Polskim Radiu Białystok. Do publikacji, skierowanej głównie do szkół oraz bibliotek w Polsce, Białorusi i Litwie, dołączono również cztery płyty $\mathrm{z}$ oryginalnymi nagraniami gawęd radiowych.

6 Serce i pazur. O uczuciach zwierzat, red. A. Błachowska, A. Andrejczuk, A. Kaczanowski, Białystok 2010. 
Pierwsza z nich charakteryzuje się wyłącznie cechami fizycznymi, takimi jak rozmiar, ruch czy kształt. W drugiej mieszczą się właściwości intelektualne oraz emocjonalne. Tylko człowiekowi Kartezjusz przypisał obie te właściwości, tym samym pozbawiając zwierzęta sfery emocjonalnej. Na reprezentowany przez to stanowisko antropocentryzm zwraca uwagę Monika Bakke w artykule Między nami zwierzętami. O emocjonalnych związkach między ludźmi i innymi zwierzętami:

w naszym obszarze kulturowym emocjonalne relacje między ludźmi a innymi zwierzętami są najczęściej całkowicie zdeterminowane przez głęboko zakorzeniony antropocentryzm wyrastający z tradycji judaistycznej i antycznej, wzmocniony następnie przez chrześcijaństwo i filozofię nowożytną z jej negatywnym apogeum, które można odnaleźć w tekstach Kartezjusza i jego uczniów. Francuski filozof uważał bowiem, iż tylko ludzie mają życie emocjonalne, co wyraża się przez śmiech, rumieniec, bladość, łzy etc., natomiast zwierzętom, będącym na swój sposób wyłącznie doskonałymi maszynami, niedysponującymi jednak życiem duchowym, odmawiał zdolności przeżywania emocji ${ }^{7}$.

Z założeniem tym, utrwalonym w nauce i kulturze, zmierzył się Karol Darwin ${ }^{8}$, który ostatecznie podważył założenia Kartezjusza wskazując, że jego metafizyka, kwestionująca fakt posiadania duszy przez zwierzęta, w potocznej świadomości stanowi usprawiedliwienie przedmiotowego traktowania zwierząt. W jednej z gawęd Kossak odniosła się do poglądów filozofa $\mathrm{w}$ charakterystyczny dla siebie sposób, zupełnie nieprzypominający stylu, jakiego można by oczekiwać od biologa. Opowiadając słuchaczom o historycznych zmianach w sposobie postrzegania zwierząt w kulturze, przywołała anegdotę dotyczącą troskliwego traktowania przez Kartezjusza psa, który mieszkał w jego domu. Filozof „dla tego jednego psa zrobił wyjątek i kokosił się z nim, głaskał, hołubił i go bardzo lubił. Natomiast na zewnątrz traktował zwierzę jak maszynę" 9 . Simona Kossak, ze względu na bliskie relacje ze zwierzętami różnego gatunku była przekonana, że zwierzętom, podobnie jak ludziom, przez całe ich życie towarzyszą różnego rodzaju emocje. W trakcie pracy nad książką Serce i pazur. O uczuciach zwierząt redaktorzy, spośród dwóch tysięcy nagrań, wybrali gawędy tematyzujące uczucia zwierząt. Kategoria „uczucia” spełnia w tej publikacji funkcję nadrzędną, porządkującą

\footnotetext{
7 M. Bakke, Między nami zwierzętami. O emocjonalnych związkach między ludźmi i innymi zwierzętami, „Teksty Drugie” 2007, nr 1-2, s. 222-223.

8 Zob. K. Darwin, O wyrazie uczuć u człowieka i zwierząt, przeł. Z. Mejlert i K. Zaćwilichowska, Warszawa 1988.

9 S. Kossak, Czy zwierzęta myślq??, https:// www.youtube.com/watch?v=QBYvHNSmVaw [dostęp 28.12.2016].
} 
zgromadzone opowiadania o różnego rodzaju zachowaniach zwierząt. Zbiór gawęd otwiera rozdział dotyczący zalet i wad zarówno życia w grupie, jak i w pojedynkę. Następnie czytelnik dowiaduje się o bogactwie sposobów komunikowania się zwierząt $w$ ramach jednego gatunku, jak też między nimi a ludźmi. Kolejne rozdziały dotyczą kłamstwa w świecie zwierząt, miłości rodzicielskiej i komunikacji rodzinnej, radości zwierząt oraz sposobów jej wyrażania poprzez zabawę. Kossak snuje również gawędy o rodzajach smutku, rozpaczy i depresji zwierząt oraz o tym, czego się one boją i jak reagują, gdy są przestraszone. Ostatnie gawędy $z$ tego zbioru tematyzują negatywne emocje, takie jak złość, złośliwość i agresja.

Gawędy Simony Kossak, jak już wcześniej podkreśliłam, nie zostały przez nią spisane. Trudno jest więc mówić w tym wypadku o intencjonalnym realizowaniu tego gatunku jako de facto literackiego. Współcześnie spotykamy się z szeregiem form konwencjonalnie nazywanych gawędami, związanych z funkcjonowaniem nowych, dawniej nieistniejących sytuacji kulturowych, nienależących do literatury, takich jak: gawęda radiowa, telewizyjna, recenzja gawędziarska, felieton-gawęda. Kossak wykorzystała gatunek gawędy, sięgając do jego korzeni, który wyrósł z żywiołu mowy, opowieści stricte ustnej. $\mathrm{Z}$ historycznej gawędy romantycznej zachowała jedynie swobodny tok wypowiedzi. Szczególną cechą budowanych przez nią historii jest emocjonalne zaangażowanie gawędziarki. Część gawęd zostało nagranych w Puszczy Białowieskiej, dzięki czemu w nagraniu słychać na przykład odgłosy ptaków czy dźwięki pracujących przy tamie bobrów. Za pośrednictwem snucia gawędy nie $\mathrm{w}$ studiu radiowym, lecz na polanie lub $\mathrm{w}$ gęsto zalesionym lesie, zwierzętom zostaje $\mathrm{w}$ pewnym sensie oddany głos, co nie jest już możliwe $\mathrm{w}$ spisanym tekście. Istotne wydaje się również to, do jakich źródeł wiedzy sięgała Kossak-gawędziarka. W swoich opowieściach często powołuje się na wspomnienia przyjaciół i znajomych. Buduje narracje, opierając się zarówno na doświadczeniach własnych, jak i cudzych. Istotnym elementem jej gawęd jest sposób ich konstruowania, przypominający snute przez Szeherezadę baśnie. Podobnie jak bohaterka Baśni tysiąca i jednej nocy, Kossak kończy gawędę informując odbiorcę, że będzie musiał poczekać do następnego nagrania, aby dowiedzieć się o kolejnych zwyczajach zwierząt. Podobnie, kiedy rozpoczyna gawędę, przypomina odbiorcom najważniejsze informacje z poprzedniej. Dzięki takiemu zabiegowi gawędy Kossak układają się w jedną spójną całość, a dodatkowo zachęcają do kolejnego wysłuchania. Taki zabieg jest widoczny jedynie $\mathrm{w}$ formie mówionej gawędy, ponieważ redaktorzy książek z tekstami gawęd zrezygnowali z tej formuły. Kolejną cechą gawęd Kossak jest ich popularnonaukowy charakter. W książce Serce i pazur próżno szukać czysto naukowych źródeł, odwołań do prac badaczy, 
specjalistów czy teoretyków. W opowieściach często pojawia się fraza "widziałam niesamowity film”, która otwiera lub podsumowuje gawędę. Wykorzystywane przez Simonę Kossak źródła uzmysławiają odbiorcy, że on również, każdego dnia, może być obserwatorem zwierząt, wyczulonym na sposób ich funkcjonowania. Kossak nie popisuje się swoją wiedzą naukową (którą przecież posiadała jako profesor nauk leśnych i biolog), nie opowiada o zwierzętach z pozycji eksperta. Do mówienia o uczuciach zwierząt wykorzystuje formę narracji zarezerwowaną dotychczas do przekazu doświadczenia ludzkiego.

Gawędy Simony Kossak nie musiały długo czekać na utrwalenie ich w formie tekstu pisanego. Jej opowieści o zwierzętach, zarówno te funkcjonujące $\mathrm{w}$ postaci nagrań, jak i te, które zostały utrwalone w piśmie, charakteryzują się podobnymi cechami. Jedną z nich jest posługiwanie się pierwszą osobą liczby mnogiej:

Nazywamy się po łacinie homo sapiens (człowiek myślący), a jesteśmy tak naprawdę homo "gadativus" (człowiek "gadający"). Gdy tylko możemy, to gadamy, a jeżeli nie możemy gadać, to i tak mamy w głowie "gadatliwy mózg". [...] Nie zdajemy sobie sprawy, jakimi mistrzami w oszukiwaniu są zwierzęta i jak bliskie jest ono ludzkiej naturze" ${ }^{10}$.

Wykorzystanie w opowieści pierwszej osoby liczby mnogiej służy nie tylko utożsamieniu się nadawcy z odbiorcą, ale umożliwia oddanie gawędziarskiego charakteru narracji. Ważnym aspektem opowieści jest również sposób, w jaki Simona Kossak określa zwierzęta. Zazwyczaj posługuje się ona zdrobnieniami, a określenie "zwierzątko" pojawia się w jej tekstach zdecydowanie częściej niż „zwierzę":

Widziałam niesamowity film, w którym w kryształowo czystej wodzie romansowały dwie ośmiorniczki. Adorowały się pływając obok siebie i zmieniając błyskawicznie kolory ciała. Było to bardzo malownicze widowisko, ponieważ kolory były piękne. Ponadto samczyk, który od strony samiczki purpurowiał ze szczęścia i z podniecenia, od strony zewnętrznej miał ubarwienie sine, blade, wręcz białe ${ }^{11}$.

Inny przykład dotyczy ciem: „Siedząca na korze brzozy, ze skrzydełkami w biało-czarne wzorki, cienie i plamki, dla człowieka przechodzącego obok drzewa [ćma - dop. K.T.] jest absolutnie niewidoczna"12. Stosowanie

\footnotetext{
10 S. Kossak, Serce i pazur, s. 45, 58.

11 Tamże, s. 32.

12 Tamże, s. 56.
} 
zdrobnień $\mathrm{w}$ opisie zwierząt $\mathrm{z}$ pewnością nie ma na celu ich trywializowania. Taki typ mowy, którego charakterystycznym elementem są zdrobnienia i spieszczenia, w badaniach dotyczących interakcji ludzi i zwierząt określa się terminem amaeru (od japońskiego amae - słodki) ${ }^{13}$. Badacze wskazują, że termin ten oznacza dodatkowo pobłażliwe traktowanie niesfornych zachowań, głównie dzieci ${ }^{14}$. W tym miejscu warto zastanowić się nad charakterem relacji Kossak z jej zwierzętami. Użyłam zaimka „,jej” nie bez przyczyny. Zarówno z tekstów Kossak, jak też jej biografii pióra Anny Kamińskiej, Simona. Opowieść o niezwyczajnym życiu Simony Kossak, wyłania się obraz kobiety troszczącej się o zwierzęta tak, jak matka o swoje dzieci. Potwierdza to sposób, w jaki mówi/pisze ona o zwierzętach, przywołujący na myśl skojarzenie matki opowiadającej o własnym dziecku. Stosunek matka-dziecko pomiędzy Kossak a zwierzętami (szczególnie ukochanymi przez nią sarnami) wart jest oddzielnej analizy. Można założyć, że liczne zdrobnienia świadczą o głębokim i szczerym uczuciu, jakim Simona Kossak darzyła zwierzęta. Zamierzonym $\mathrm{w}$ tym przypadku efektem jest uwrażliwianie odbiorcy na los zwierząt.

Kolejną cechą gawęd Simony Kossak jest dopisywanie myśli zwierząt w trakcie tworzenia narracji. Przykładem może być fragment, w którym opisuje ona zachowanie psa:

Nie tylko ludzie są tacy sprytni. Właściwie okazuje się, że nic nie potrafimy wynaleźć, czego przyroda już dawno nie wymyśliła. Najprostszy przykład to piesek na spacerze, który podchodzi do najbliższego słupa czy drzewa, podnosi łapę i leciutko obsikuje (tak właśnie działa zwierzęca ",automatyczna sekretarka"!) wraca ze spaceru do domu i wygrzewa się przy kominku, a w tym czasie inny pies podchodzi i wącha oznakowane miejsce. Odczytuje wiadomość: „,ja tu byłem, to jest mój rewir, codziennie chodzę tu ze swoją panią." Ten drugi pies podnosi więc łapę i sika trochę wyżej. Jest to komunikat zostawiony dla pierwszego psa „,nie myśl sobie stary, że ty jeden po dzielnicy chodzisz. Tutaj jest też moje miejsce. Ja jestem również silnym i dzielnym psem". Są to komunikaty zostawione świadomie ${ }^{15}$.

W bardzo wielu tekstach Simony Kossak zwierzęta „wypowiadają się” oraz „komunikują" , a więc zostają dopuszczone do głosu. Gawędziarka tłumaczy odbiorcom zachowania zwierząt, przykładając do ich postępowania

13 B. Mirucka, U. Bielecka, Intrapsychiczne i interpersonalne funkcje relacji człowieka ze zwierzęciem towarzyszacym, „Psychologia Społeczna” 2014, t. 9, nr 3, s. 340.

14 K. Konecki, Dotyk i wymiana gestów jako element wytwarzania więzi emocjonalnej. Zastosowania socjologii wizualnej i metodologii teorii ugruntowanej w badaniu interakcji zwierząt $i$ ludzi, „Przegląd Socjologii Jakościowej" 2008, t. 4, nr 1, s. 76.

15 S. Kossak, Serce i pazur, s. 40-41. 
słowa i określenia zarezerwowane dla człowieka, takie jak zdrada, ślub czy małżeństwo. Ma to na celu nie tylko wzbogacenie narracji, ale również wyartykułowanie głównej tezy Kossak, że nie tylko ludzie, ale również zwierzęta myślą oraz porozumiewają się ze sobą. W swoich gawędach Kossak posługuje się również ironią, która pojawia się wyłącznie w wypowiedziach dotyczących ludzi, nigdy zwierząt. Ślady ironii można zauważyć już we wcześniej przytoczonych przeze mnie fragmentach, np. w wyrażeniu homo "gadativus". Interesujący jest sposób, w jaki Kossak odnosi się do wiedzy naukowej oraz samych naukowców:

Są oczywiście tacy uczeni, którzy potrafią wszystko w sposób naukowy i cyniczny wydrwić. Oni twierdzą, że altruizm wśród zwierząt nie istnieje. Ich zdaniem w każdym takim zachowaniu zwierząt można doszukać się jakichś ich korzyści. [...] Szukanie w tym jakichkolwiek interesownych pobudek jest w moim przekonaniu nieuczciwością ${ }^{16}$.

Ironia okazuje się niezwykle przydatnym narzędziem do ukazania tego, że ludzie nieuzasadnienie stawiają siebie wyżej od zwierząt. Doskonałym przykładem wykorzystania przez Kossak ironii jest to, w jaki sposób opisuje ona zachowania ludzi i zwierząt:

W półkulach mózgowych znajduje się źródło pewnych reakcji i zachowań. To one świadczą o tym, że jesteśmy istotami kulturalnymi i rozumnymi. Kultura zachowań jest właśnie zależna od nich. U zwierząt półkule mózgowe są małe, a u ludzi natomiast ogromne. Zwierzęta może i mają je maleńkie, ale mimo tego jakie są kulturalne! A człowiek (z tym wielkim mózgiem) jakim potrafi być... „bezinteresownym chamem" ${ }^{\prime 17}$.

O ludziach i ich postępowaniu Simona Kossak nie miała najlepszej opinii. Może właśnie dlatego była w lepszych kontaktach ze zwierzętami niż ludźmi:

Dzik będzie wchodził do jej łóżka, rysica spała w nogach, jamniczka jadła z talerza, a oślica wyjmowała z ust papierosa. Gadający kruk będzie skubał jej włosy, a popielice chodziły po jej domu jak ptaki, z którymi zamieszka: sowa, puchacz czy czarny bocian. [...] Z nikim z rodziny czy znajomych nie stworzy tak silnej relacji jak ze stadem hodowanych przez siebie saren ${ }^{18}$.

Zwierzęta Simony Kossak pełnią funkcję tak zwanych zwierząt towarzyszących (companion animals), które są przez człowieka pielęgnowane:

16 Tamże, s. 16-21.

17 Tamże, s. 53.

18 A. Kamińska, Simona, s. 41-42. 
Pojęcie „zwierzę towarzyszące" odnosi się [...] do takiego zwierzęcia, które jest dla danej osoby obiektem znaczącym i z którym łączy ją bliska więź. [...] zwierzęciem towarzyszącym może być każde zwierzę niezależnie od gatunku (m.in. ptaki, gryzonie, płazy, gady, ryby, konie itd.), o ile tylko stanowi ważny obiekt relacji ${ }^{19}$.

Kategoria „zwierzęcia towarzyszącego" w kulturze zachodniej odnosi się do przyjaźni człowieka z psem czy kotem ${ }^{20}$. Bliska relacja Kossak ze zwierzętami, które są uznawane przez człowieka za dzikie, a tym samym często niebezpieczne - jak na przykład dzik - stanowi zachętę do przemyślenia kategorii zwierzęcia towarzyszącego ${ }^{21}$. Takim postępowaniem Kossak skłania do refleksji na temat kulturowego uwarunkowania podziału na zwierzęta dzikie i udomowione.

Swoje ekogawędy Kossak poświęciła zwierzętom oraz roślinom. W Opowiadaniach o ziołach $i$ zwierzetach: zgodnie $z$ natura swojego gatunku (1995) w formie krótkich literackich opowiadań, autorka opisała osiemdziesiąt dwa gatunki roślin i zwierząt. W 1998 roku wyszła kolejna jej książka o przekornym tytule Wilk - zabójca zwierząt gospodarskich?, zaś ostatnia była Saga Puszczy Białowieskiej (2001), na którą warto zwrócić szczególną uwagę ze względu na jej aktualność. Już ponad piętnaście lat temu Simona Kossak podjęła wciąż nierozwiązany problem, który w ostatnim czasie staje się zarzewiem coraz głośniejszych konfliktów ${ }^{22}$.

W podsumowaniu warto zastanowić się nad powodami wyboru przez Simonę Kossak właśnie gawędy jako formy opowieści o zwierzętach, skierowanej do szerokiej publiczności. Gawęda jest formą dość pojemną, gdyż $\mathrm{w}$ jej ramach mogą pojawić się dygresje oraz liczne odwołania do osobistych i cudzych doświadczeń. W swoich gawędach o zwierzętach Simona Kossak

19 B. Mirucka, U. Bielecka, Intrapsychiczne i interpersonalne, s. 338.

20 Problem współistnienia zwierząt i ludzi podejmowali różni badacze. Zob. É. Baratay, Zwierzęcy punkt widzenia: inna wersja historii, przeł. P. Tarasewicz, Gdańsk 2014; J. Ullrich, Strefy kontaktu. Spotkanie psa i człowieka (Psio-ludzkie metamorfozy w sztuce wspótczesnej, przeł. E. Ulińska, w: Zwierzęta i ich ludzie: zmierzch antropocentrycznego paradygmatu, red. A. Barcz, D. Łagodzka, Warszawa 2015, s. 88-106.

21 Przykłady bliskiej relacji z dzikim zwierzęciem można znaleźć w albumie partnera Simony Kossak, Lecha Wilczka, fotografa, Spotkanie z Simona Kossak, Białowieża 2011.

22 Spór wokół Puszczy Białowieskiej trwa od lat, z większą lub mniejszą intensywnością. Dotyczy on głównie dwóch problemów. Pierwszy z nich odnosi się to tego, jaki obszar Puszczy ma być objęty ścisłym rezerwatem Parku Narodowego. Drugi dotyczy wniosków o powiększenie wycinki Puszczy w celu zlikwidowania gradacji kornika drukarza (Ips typographus). Simona Kossak również ustosunkowała się do sporów dotyczących Puszczy Białowieskiej. Zob. S. Kossak, Śmierć Puszczy, „Gazeta Wyborcza” 1992, nr 136, s. 12. 
pokazuje, że człowiek wciąż zajmuje wobec nich pozycję uprzywilejowaną. Jak zauważa Anna Barcz we Wprowadzeniu do zookrytyki (teorii zwierzęcych narracji)

To człowiek tworzy narracje o zwierzętach, dlatego zookrytyce bliski jest warsztat filologa. Od zoofilologii i innych koncepcji zorientowanych na interpretację obecności zwierząt w tekstach kultury różni ją to, co dotyczy roli człowieka, wyciszenia jego/jej głosu na rzecz wydobycia głosu zwierząt ${ }^{23}$.

Z taką sytuacją nie mamy jednak do czynienia w gawędach Simony Kossak. Jej narracje dowodzą wyraźnie, że to ona próbuje mówić głosem zwierząt. Nie szuka innych, alternatywnych, sposobów na ich obecność w tekście. Determinuje to formę gawędy: $\mathrm{z}$ wyraźnie obecnym, subiektywnym, ludzkim głosem narratora, użyczającym zwierzętom głosu zgodnie ze znaną z bajek konwencją, jaką jest przypisywanie im wypowiedzi w ludzkim języku, a tym samym ludzkiego sposobu myślenia. Kossak wyraźnie stawia siebie w roli "gospodarza". Budowana jest w ten sposób postać narratora-gawędziarza, będącego w centrum opowieści i decydującego o jej przebiegu. $\mathrm{Z}$ jednej strony autorka, mimo deklaracji bycia po stronie przyrody, swoimi gawędami utrwala pewien stereotypowy sposób patrzenia na relację zwierząt i ludzi. Z drugiej strony obecność człowieka, wpisana $w$ taką formę narracji jak gawęda, pozwala uzyskać zamierzone efekty - zachęcić do zainteresowania się zwierzęcą perspektywą - a jednocześnie dotrzeć do szerokiego grona odbiorców. Dodatkowo gawęda, w przeciwieństwie do tekstu naukowego, zmniejsza dystans pomiędzy nadawcą a odbiorcą. W tekstach naukowych Simona Kossak musiała traktować zwierzęta oraz środowisko naturalne jako przedmiot badań, co widać chociażby w tytułach jej publikacji, takich jak: Liczebność zwierzyny w Puszczy Białowieskiej i proponowane sposoby prowadzenia gospodarki towieckiej ${ }^{24}$ czy Strefowe zróżnicowanie ochrony i użytkowania zwierzyny na przykładzie Biebrzańskiego Parku Narodowego i terenów z nim sąsiadujących ${ }^{25}$ Za pośrednictwem gawęd Kossak dokonuje zmniejszenia dystansu, dzięki czemu zwierzęta nie są w nich przedmiotem, lecz podmiotem opowieści. Nie byłoby to jednak możliwe bez „przekroczenia kordonu", stanięcia po stronie zwierząt. Zookrytyka wymaga, aby w narracji

23 A. Barcz, Realizm ekologiczny. Od ekokrytyki do zookrytyki w literaturze polskiej, Katowice 2016, s. 321.

24 S. Kossak, Liczebność zwierzyny w Puszczy Białowieskiej i proponowane sposoby prowadzenia gospodarki towieckiej, „Sylwan” 1995, nr 8, s. 25-41.

25 S. Kossak, Strefowe zróżnicowanie ochrony i użytkowania zwierzyny na przykładzie Biebrzańskiego Parku Narodowego i terenów z nim sąsiadujących, „Chrońmy Przyrodę Ojczystą” 1999, nr 1, s. 18-34. 
oddać głos zwierzętom i pokazać, że są one świadome własnego zachowania. Kossak nie robi tego w pełni, jednak o czym świadczą efekty jej działalności - odnosi zamierzony skutek. W twórczości ekogawędowej Kossak dominuje aspekt ekokrytyczny. Gawędy nie mogą być rozpatrywane w oderwaniu od jej życia, skupionego wokół ochrony natury. Są więc z pewnością formą aktywności zaangażowanej, której zadaniem jest uwrażliwienie ludzi na los zwierząt.

\section{Eco-tales by Simona Kossak}

\section{Summary}

This article discusses the life and work of Simona Kossak, a writer and professor of forestry. Her life work aimed at awakening in her readers and listeners sensitivity and compassion towards animals and natural surroundings. The author examines Kossak's radio talks which she proposes to name "eco-tales".

Keywords: ecocriticism, eco-tales, ecology, Simona Kossak 